DOI https://doi.org/10.30525/978-9934-588-91-4-33

\title{
ПОЛІТИКА УРЯДУ ПОЛЬЩІ ЩОДО ЕВРЕЙСЬКОЇ ОБЩИНИ ТА ЗБЕРЕЖЕННЯ ПАМ'ЯТІ ЖЕРТВ ГОЛОКОСТУ
}

\author{
Козерод О. В. \\ доктор історичних наук, старчий науковий співробітник \\ Інституту політичних і етнонаціональних досліджень \\ імені I. Ф. Кураса Національної академї̈ наук Украӥни \\ м. Київ, Україна
}

Активна участь польської держави у розвитку єврейської культури, створенні музеїв Голокосту, реставрації синагог і молитовних будинків останніми роками стала позитивним прикладом політики щодо єврейської общини, який виділяється на тлі не тільки регіону Східної Європи, а й усього європейського континенту.

Одним з важливих елементів цієї політики $є$ проведення масштабних наукових досліджень, спрямованих на знаходження нових історичних фактів й увічнення подвигу поляків, які рятували євреїв в період Голокосту. Велику роботу в цьому напрямку проводить Міністерство закордонних справ Польщі, укомплектоване коштом багатьох істориків, що перейшли на дипломатичну службу. На початку вересня 2020 року Посольство Польщі в Ізраїлі опублікувало електронну книгу про діяльність польських дипломатів під час Другої світової війни, зокрема про зусилля з порятунку євреїв від Голокосту. У книзі розповідається про групу польських дипломатів часів Другої світової війни, що працювала в Берні й підробила сотні паспортів, які допомогли врятувати євреїв від Голокосту [1].

Ця книга написана на івриті й викладена на сайті посольства Польщі в Тель-Авіві. Електронна книга містить 24 оповідання, які описують широкий спектр подій та епізодів, що відображають роботу дипломатів Польщі під час війни. Серед них: історія про зашифровану телеграму, направлену міністром закордонних справ Польщі Юзефом Беком в польські посольства Парижа та Лондона 1 вересня 1939 року 3 вимогою повідомити тамтешньому уряду про німецьке вторгнення в Польщу, а також історія польського посла в Москві Вацлава Гжибовського, який відмовився прийняти дипломатичну ноту, що виправдовує радянську агресію проти Польщі 17 вересня, та інші. Електронна книга також містить безліч матеріалів, присвячених польсько-єврейським відносинам [1].

Одна 3 історій нагадує про історичний концерт піаніста польськоєврейського походження Артура Рубінштейна в ООН в Сан-Франциско у 1945 році. Обурений тим, що Польщу не запросили на конференцію, 
Рубінштейн припинив грати на піаніно та попросив аудиторію, в яку входила радянська делегація, встати. Він сказав: «У цьому залі, де зібралися великі народи, аби зробити цей світ кращим, я не бачу прапора Польщі, від імені якої велася ця жорстока війна, і тепер я буду грати польський національний гімн» [1].

Зміст даної книги перегукується зі змістом англомовної книги, що була представлена МЗС Польщі в Wiener Holocaust Library в Лондоні й також присвячена роботі польських дипломатів в Берні, які рятували євреїв в період Голокосту. У так званому «Списку Ładoś» наводяться відомості про людей єврейського походження, які отримали підроблені паспорти від групи польських дипломатів, що прагнули врятувати людей від нацистів під час Другої світової війни. Книга отримала свою назву на честь Олександра Жадога, польського дипломата, який під час війни очолював неформальну групу в Берні (Швейцарія), що виготовляла паспорти для євреїв з гетто в окупованій німцями Польщі. «Список Ładoś» був опублікований польською мовою в грудні 2019 року Польським інститутом Пілецького. Він містить імена понад 3000 осіб єврейського походження, які отримали підроблені паспорти нейтральних країн. Книгу також було представлено в Hebrew Union College в Нью-Йорку [2].

Слід зазначити, що окрім проведення історичних досліджень важливою частиною політики польського уряду $є$ боротьба 3 крайніми правими партіями, які прагнуть принизити або нівелювати значення трагедії Голокосту. Так, польські політичні лідери блокували резолюцію, яка мала зупинити реституцію майна, втраченого євреями під час Голокосту. Правляча партія Польщі PiS рішуче виступила проти пропозиції крайніх правих сил, які вимагали зупинити реституцію власності, що належала євреям та іншим особам до початку Голокосту [3].

Крайні праві активісти зібрали достатньо підписів, аби представити цей проект резолюції в Сейм, нижню палату польського парламенту, який заборонив би перерозподіл «спадкової власності» - власності, що належала приватним особам. Багато 3 них були євреями, яких було вбито під час Голокосту і чиї спадкоємці, якщо вони існують, ніколи не подавали заяв на реституцію. «Забороняється вживати будь-які дії, спрямовані на задоволення претензій щодо майна його спадкоємцями, включно із переговорами, укладенням розрахунків, визнанням претензій та дій, що стосуються майна, а також згодою на посередництво, переговорами сторін з посередництва або виплатою грошових компенсацій» [3], - йдеться в проекті. У ньому також говориться про те, що нацистська Німеччина, а не Польща, несе відповідальність за все, що сталося в Польщі, коли вона була окупована Німеччиною. Виступаючи від імені партії «Право і справедливість», депутат Аркадіуш Муларчік сказав, що в проекті резолюції немає необхідності, оскільки «проблеми безхазяйних земель в Польщі насправді не існує». Мацей Конєчний, 
депутат «Left Together», назвав проект антисемітським, додавши, що це була «кампанія залякування євреїв, які, на думку іiі ініціаторів, збираються пограбувати Польщу» [3]. За даними Всесвітньої організації реституції євреїв, Польща вже повернула мільйони доларів в якості компенсації за власність, що належала єврейським общинам, але це єдина велика країна в Східній Свропі, яка поки що не вжила жодних заходів щодо повернення приватної власності її спадкоємцям.

Політика уряду Польщі щодо єврейської общини реалізовується на тлі зростаючого антисемітизму в регіоні Східної Свропі, про який останнім часом попереджає багато експертних організацій. Так, опитування Антидефамаційної ліги (ADL) свідчать про зростання антисемітських настроїв в Східній Європі. Антидефамаційна ліга опублікувала сьогодні результати соціологічного опитування, проведеного цього року, яке охопило близько 9000 осіб в 18 країнах [4]. Дані переважно узгоджуються iз результатами попередніх опитувань, проведених в цих країнах 2017 року, проте Україна, Польща, Угорщина і Росія показали істотне зростання. У цих країнах 46\%, 48\%, 42\% й 31\% відповідно з 2015 опитаних за випадковою репрезентативною вибіркою продемонстрували те, що ADL вважає «антисемітськими настроями» [4]. В опитуванні 2017 року показники країн були набагато нижчими: в Україні, Польщі та Угорщини - 32\%, 37\% й 40\% відповідно. У Росії цей показник підскочив з 23\% під час попереднього опитування 2015 року до $31 \%$ цього року. Водночас серед країн Західної Європи Швеція посіла найнижче місце за «індексом антисемітизму» (4\%). У Бельгії соціологи ADL зафіксували зростання антисемітизму на 24\%, що на три пункти більше, ніж 2017 року. У Франції цей показник залишився без змін з 2015 та 2017 років (17\%). У Сполученому Королівстві цього року він становив 11\%, що на один пункт нижче рівня 2017 року. «Ми глибоко стурбовані тим, що приблизно кожен четвертий європеєць має ті антисемітські переконання, які існували ще до Голокосту», - сказав сьогодні репортерові агентства ЈТА Джонатан А. Грінблатт, генеральний директор ADL. Під час опитування респондентів просили схвалити ті чи інші твердження, що стосуються євреїв, зокрема «У євреїв занадто багато влади в діловому світі», «Свреї несуть відповідальність за більшість світових воєн» тощо [4].

Політика польського уряду щодо «єврейського питання» пройшла протягом 2010-х років значну трансформацію - від підтримки крайніх правих організацій, традиційно налаштованих до євреїв вороже, до державної підтримки єврейської культури, відновлення синагог й надання десяткам тисяч жителів Ізраїлю польського громадянства. Польський уряд під час правління партії «Право і справедливість» вперше за багато років розвиває програми увічнення пам'яті представників польської держави, які рятували євреїв в період Голокосту. Це 
вселяє довіру й стриманий оптимізм щодо майбутнього єврейської общини в Польщі.

\section{Література:}

1. Polish embassy in Israel publishes e-book on WWII diplomacy // Polskie Radio. - 3 September 2020. URL: https://www.polskieradio.pl/ 395/7784/Artykul/2575212

2. English language «Lados List» world premiere in London// Poland In. 25 February 2020. URL: https://polandin.com/46818097/englishlanguage-lados-list-world-premiere-in-london

3. Poland blocks bill that would prevent restitution of private Jewish property by Cnaan Liphshiz // The Times of Israel. 16 April 2020. URL: https://www.timesofisrael.com/poland-blocks-bill-that-would-preventrestitution-of-private-jewish-property/\#gs.fllmp5

4. Antisemitic attitudes growing in Poland, finds new international survey // Notes from Poland. 21 November 2019. URL: https://notesfrompoland.com/2019/11/21/poland-tops-international-index-ofantisemitic-attitudes/ 